\title{
GEOLOGIA E GÊNESE DOS DEPÓSITOS DE CAULIM FLORESTA E CAMBUÍ (FORMAÇÃO CAMPO ALEGRE - SC) - 1. FACIOLOGIA E MINERALOGIA DAS ROCHAS E MINÉRIOS
}

\author{
JOÃO CARLOS BIONDI* \& LÚCIO IRAJÁ FURTADO*
}

\begin{abstract}
RESUMO Os depósitos de caulim Cambuí e Floresta estão em meio a rochas da Formação Campo Alegre, uma bacia tardi-orogênica constituída por rochas vulcânicas predominantemente ácidas, datadas em 536+65 Ma, e por rochas vulcano-sedimentares. Todas as rochas dos depósitos estão argilizadas, mas foi possível identificar as rochas vulcânicas originais e caracterizar várias fácies argilosas. Várias feições geológicas são comuns aos dois depósitos mapeados: (a) Presença de uma ou mais intrusões ácidas (diques ou apófíses); (b) Essas intrusões estão encaixadas por tufos e brechas; (c) Dentro e próximo dessas intrusões há veios e vênulas brancos que, localmente, formam stockworks preenchidos por material argiloso; (d) Localmente há recobrimento do minério disseminado, formado por caulinização pervasiva, por camadas de argilitos maciços, grauvacas e conglomerados, com concentrações de matéria orgânica vegetal oxidada na base; (e) Todas as rochas de ambos os depósitos estão cobertas por mantos espessos de solos com cores bege e negro. As seguintes fácies de rochas argilosas foram identificadas: (a) Minério branco ou vermelho-esbranquiçado (riólitos e/ou dacitos laminado argilizados); (b) Minério verde (tufos e brechas dacítico argilizados); (c) Minério sedimentar branco, maciço (d) Minério sedimentar bege, com fragmentos de matéria orgânica; (e) Rocha micácea esveredeada (alterações relacionadas às fraturas, dentro do minério branco); (f) Argila branca que preenche as vênulas e veios; (g) Solo negro.

Os depósitos de caulim Cambuí e Floresta formaram-se em ambientes vulcânicos próximais, e apresentam fácies litológicas típicas das regiões de conduto e cone vulcânicos. A mineralogia das fácies argilosas permite estabelecer uma seqüência evolutiva entre a fácies de fratura, micácea, que provavelmente é hidrotermal de alta temperatura $\left(300^{\circ} \mathrm{C}\right.$ a $\left.500^{\circ} \mathrm{C}\right)$, até a fácies venular, caulínica, que provavelmente é de média a baixa temperatura $\left(100^{\circ} \mathrm{C}\right.$ a $\left.300^{\circ} \mathrm{C}\right)$. A fácies venular grada para as fácies supergênicas, de baixa temperatura $\left(20^{\circ} \mathrm{C}\right.$ a $\left.50^{\circ} \mathrm{C}\right)$. Caso a supergênese tenha se iniciado apenas após a exumação das rochas hidrotermalisadas, há uma gradação composicional, mas não temporal, entre os fácies venular e supergênico.
\end{abstract}

Palavras-chaves: depósito de caulim, mineralogia de argilas, alterações hidrotermais, alteração supergênica, Campo Alegre.

ABSTRACT GEOLOGY AND GENESIS OF THE FLORESTA AND CAMBUI KAOLIN DEPOSITS (CAMPO ALEGRE FORMATION - SC) -1. FACIOLOGY AND MINERALOGY OF THE ROCKS AND ORES Cambuí and Floresta kaolin deposits occur within the rocks of Campo Alegre Formation, a tardi-orogenic basin filled with volcanic acidic rocks, dated as 536 $\pm 65 \mathrm{Ma}$, and volcano-sedimentary rocks. All mapped rocks in deposits are argillised, but mapping allowed to identify original volcanic rocks and to distinguish several argillaceous facies. The common features observed in both mapped deposits were: (a) Acidic intrusions are always present; (b) Intrusive rocks are hosted by tuffs and volcanic breccias; (c) Veins and fractures are inside and next to intrusions, forming stockworks filled with white argillaceous materials; (d) Locally argillaceous ores are overburden by massive beds of argillite, greywakes and conglomerates. These sedimentary beds contain buried vegetal organic debris at their basal portions, (e) All rocks of both deposits are covered by beige and black massive soils. The identified argillaceous facies were: (a) white or white-reddish ore (argillised laminated rhyolites and/or dacites); (b) green ore (argillised andesitic tuffs and breccias); (c) white massive sedimentary ore; (d) beige massive soil with vegetal organic residues; (e) micaceous, green fractures related rocks, inside the white ore; (f) white argillaceous material that fills veins in stockworks; and (g) black soils.

Cambuí and Floresta kaolin deposits were originated in volcanogenic proximal environments, and they have typical conduct and volcanic cone lithofacies. The mineralogy of the argillised rocks allowed to recognize an evolutionary sequence that starts with the fracture, micaceous, hydrothermal high temperature facies $\left(300^{\circ} \mathrm{C}\right.$ to $\left.500^{\circ} \mathrm{C}\right)$ changing upward and laterally to the stockwork-vein, kaolinic, facies, probably formed at low temperature $\left(10 \mathrm{CTC}\right.$ to $\left.300^{\circ} \mathrm{C}\right)$. The stockwork facies grades, without apparent discontinuity, to the supergenic, low temperatures $\left(20^{\circ} \mathrm{C}\right.$ to $50^{\circ} \mathrm{C}$ ) altered rocks. If supergenesis started only after hidrothermal rocks have been exhumed, a compositional but not a temporal gradding exists.

Key-words: kaolim deposits, clay mineralogy, hydrothermal alteration, supergenic alteration, Campo Alegre.

INTRODUÇÃO Na região de Campo Alegre (SC) existem cerca de 50 depósitos de caulim conhecidos. Os minérios desses depósitos abastecem as indústrias que produzem cerâmicas de mesa, de revestimento, refratária e elétrica dos Estados de Santa Catarina e Paraná. Todos esses depósitos distribuem-se em uma região restrita, conhecida como Bacia de Campo Alegre, nas proximidades da cidade homônima, e constituindo um distrito mineiro de grande importância regional. Várias empresas detém os direitos de lavra desses depósitos. A mina Floresta, instalada sobre o depósito Floresta, é propriedade da Cerâmica Oxford S.A., e a mina Cambuí, que lavra o depósito Cambuí, é da Incepa S.A. Ambas estão entre as maiores minas da região, produzindo caulim há mais de 15 anos.

GEOLOGIA REGIONAL A bacia de Campo Alegre foi geologicamente mapeada por Daitx (1979) e teve sua geologia revista por Silva (1987), durante a elaboração do Mapa Geológico do Estado de Santa Catarina na escala $1: 500.000$. É uma bacia vulcano-sedimentar composta essencialmente por vulcanites ácidos e sedimentos derivados com todas as características de uma bacia tardi-orogênica. Suas rochas vulcânicas foram datadas pelo método $\mathrm{Rb}-\mathrm{Sr}$ em $536 \pm 65 \mathrm{Ma}$ (BaseiaTeixeira 1987).

A Formação Campo Alegre pertence ao Grupo Itajaí e foi dividida por Daitx (1979) e Silva (1987) em cinco unidades (Fig. 1), resumidamente descritas a seguir, na ordem que se empilham, do topo para a base:

- Seqüência sedimentar superior, composta por siltitos, às vezes calcíferos, cinzas e tufos vulcânicos.

- Seqüência vulcânica superior, composta por derrames e diques de riólito, dacito, ignimbrito e quartzo-traquito associados a tufos e brechas ácidos, e raros siltitos e cinzas vulcânicas.

- Seqüência sedimentar intermediária, com siltitos, arcóseos e tufos, seguidos de derrames andesíticos no topo.
- Seqüência vulcânica inferior, composta por derrames de basaltos e andesitos, alguns dacitos e raros siltitos e tufos.

- Seqüência sedimentar inferior, inteiramente sedimentar, com uma fácies arcoseana e uma conglomeráticas política, com raros argilitos.

As circunferências da figura 1 mostram as posições de afloramentos dos depósitos de caulim conhecidos na região. Alguns estão sendo lavrados ou estão em fase de pesquisa e outros já foram esgotados. Os depósitos das minas Floresta e Cambuí estão indicados pelas letras F e C, respectivamente. Notar que todos os depósitos de caulim conhecidos estão em meio a rochas da Seqüência Vulcânica Superior.

GEOLOGIA DOS DEPÓSITOS DAS MINAS FLORESTA E CAMBUí Mina de caulim Cambuí A Mina Cambuí é a maior da região de Campo Alegre, e a área exposta pela lavra permite reconhecer diversas fácies vulcânicas típicas de locais próximos a condutos vulcânicos (Fig. 2). Todas as rochas aflorantes na área lavrada estão argilizadas, e as fácies vulcânicas originais podem ser identificadas pelas estruturas das rochas preservadas da argilização.

Houve, no local, uma primeira fase de vulcanismo que formou espessos pacotes de brechas, aglomerados vulcânicos (figuras 3 e 4) e tufos de menor granulometria, ambos com matrizes de cores verde e fragmentos brancos, avermelhados ou verdes. Esses tufos constituem um dos principais tipos de minério desta mina, que será doravante denominado de minério disseminado verde por ser constituído por argilo-minerais disseminados, formados por alterações hidrotermal e supergênica pervasivas. Conforme será discutido posteriormente, as análises químicas dessas rochas sugerem que tenham sido vulcanites de composições intermediárias, provavelmente dacítica ou andesítica. Os planos de estratificação medidos nas brechas mostram direções próximas de N5E, e mergulhos $35-45^{\circ} \mathrm{NW}$. Na parte leste da mina afloram, intercalados nessas brechas, tufos cineríticos e lapílicos com matriz de opala (figura 5). 
A Segunda fase vulcânica é constituída essencialmente por rochas intrusivas. Há três grandes diques de riólito fluidal bem laminado (figura 2), um dique de riólito maciço e um pequeno dique de andesito, todos intensamente argilizados. Os riólitos fluidais argilizados são branco avermelhados e têm contatos nítidos com as brechas verdes (figura 6). Esses dique apresentam direções próximas de NS e mergulhos de cerca de $70^{\circ}$ para W. Quando intensamente argilizados os riólitos laminados são lavrados fornecendo o minério disseminado branco. As análise químicas feitas revelam que essas rochas são muito mais silicosas que o minério verde, indicando provável composição original riolítica.

Todas as rochas vulcânicas são recobertas por solos espessos de cores e texturas variadas. Na superfície o solo argiloso é negro (figuras 3 e 4), com muitas raízes de plantas e restos de matéria orgânica. Na parte central da mina (Fig. 2), abaixo do solo negro há espessos pacotes de argilitos maciços com fragmentos de raízes. Geralmente esses solos têm cores creme ou branca. São solos recentes que se desenvolvem sobre as rochas vulcânicas argilizadas. Os argilitos creme e branco são

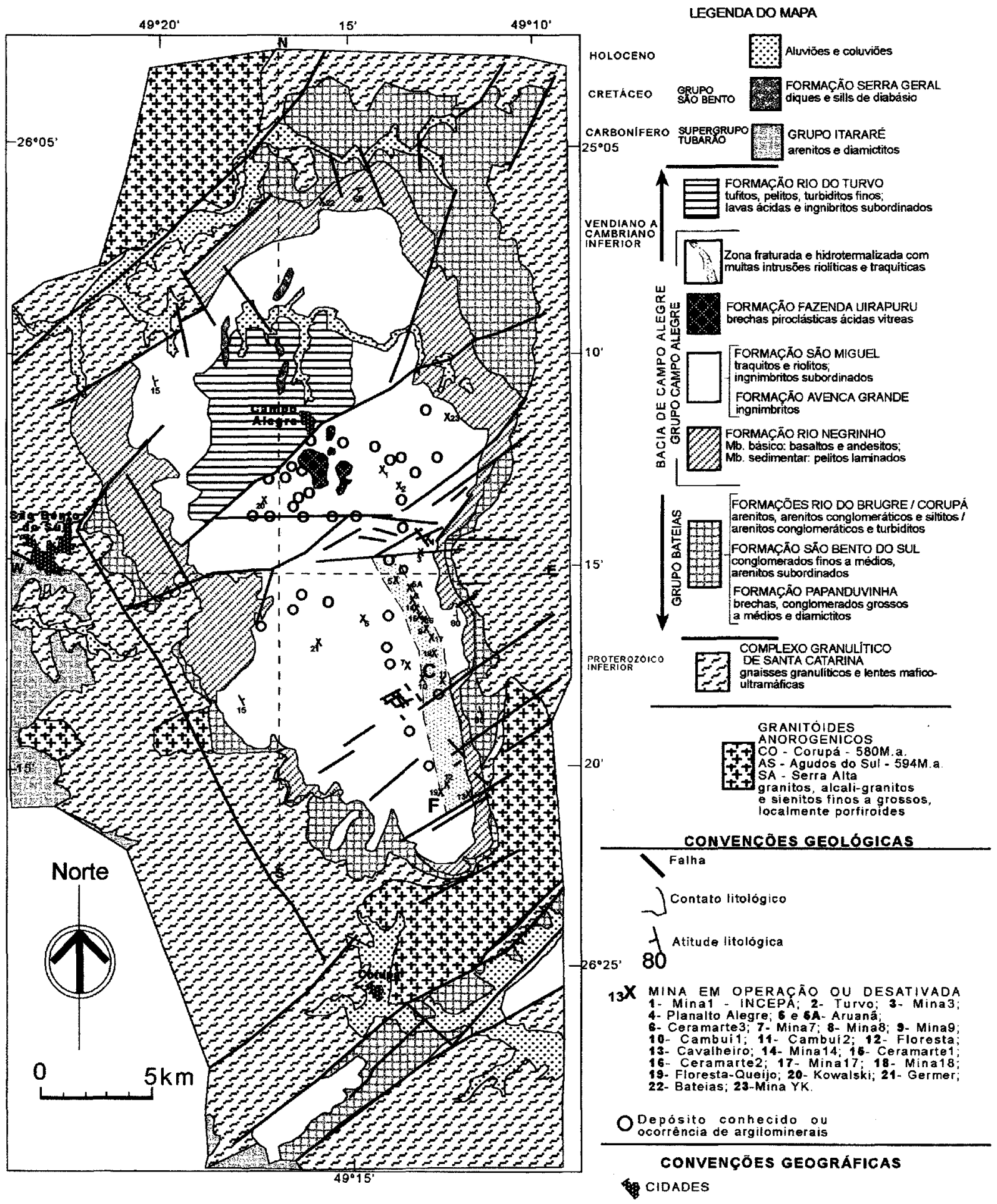

Figura 1 - Mapa geológico da Formação Campo Alegre (SC, Brasil). As circunferências indicam os principais depósitos de caulim conhecidos na região $(F=$ Mina da Floresta e $C=$ Mina Cambui $)$. 
lavrados e constituem o minério retrabalhado, assim denominado em alusão ao fato de mostrarem feições de deslizamento sobre as rochas sotopostas.

Dentro dos diques de riólitò há locais intensamente brechados, com estruturas típicas de stockworks (figuras 7 e 8) que têm formas arborescentes e são preenchidos por material argiloso branco, denominado venular. Essa venulação é particularmente intensa dentro e nos contatos dos diques de riólito fluidal, diminuindo com o afastamento dos contatos desses diques. Dentro do minério verde a venulação é menos densa e orientada plano-paralelamente, sempre com preenchimento de material argiloso branco (figura 9).

Em alguns locais, junto às falhas, fraturas e contatos intrusivos, as rochas mostram cores esverdeadas claras. Essas rochas são diferentes na cor e na textura do minério disseminado verde porque provavelmente estão relacionadas à percolação de fluidos que percolaram esses locais, favorecidos pela permeabilidade dessas discontinuidades. Esse tipo de rocha foi denominado de fácies de fratura.

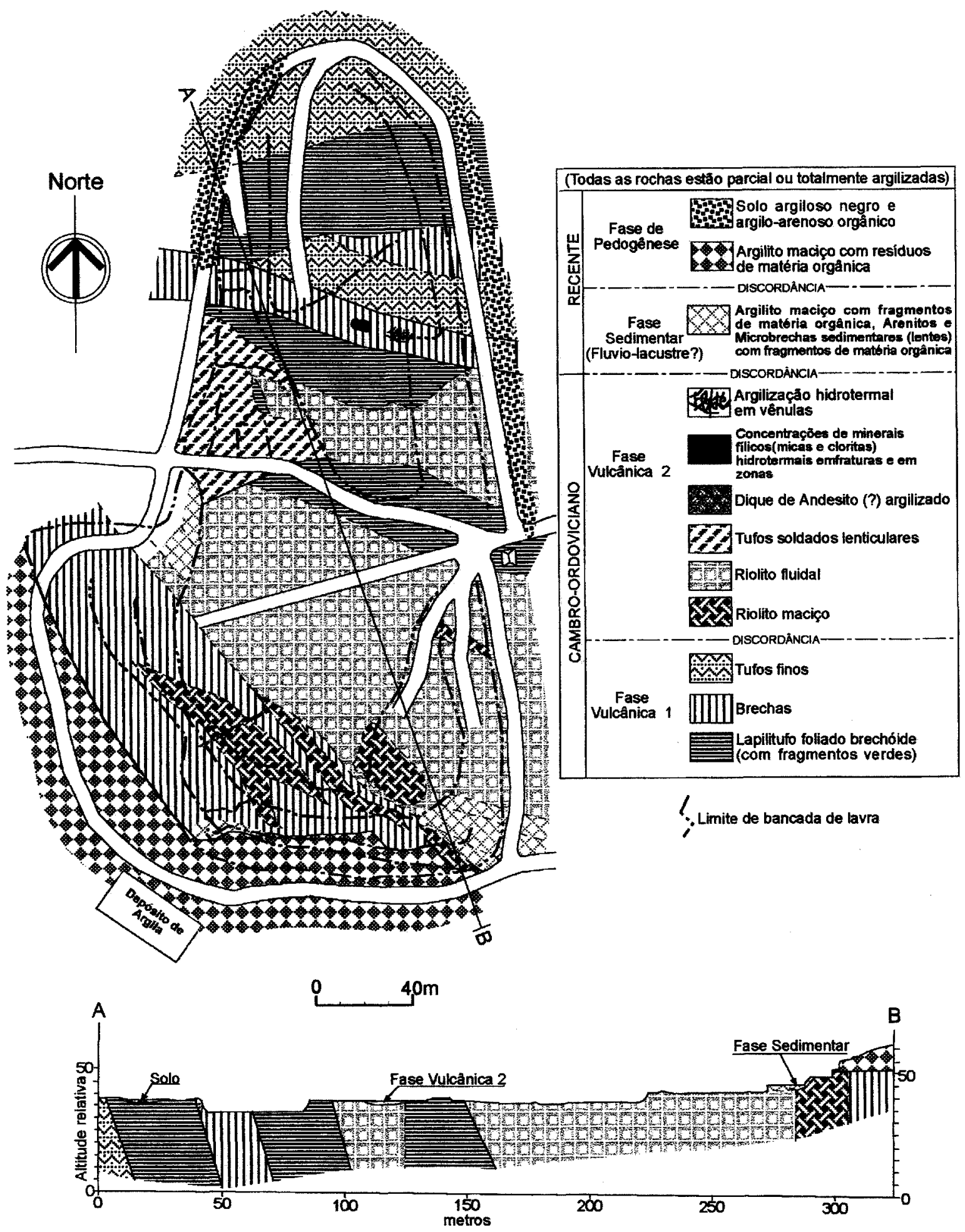

Figura 2: Mapa geológico da Mina de caulim Cambui (SC, Brasil). 


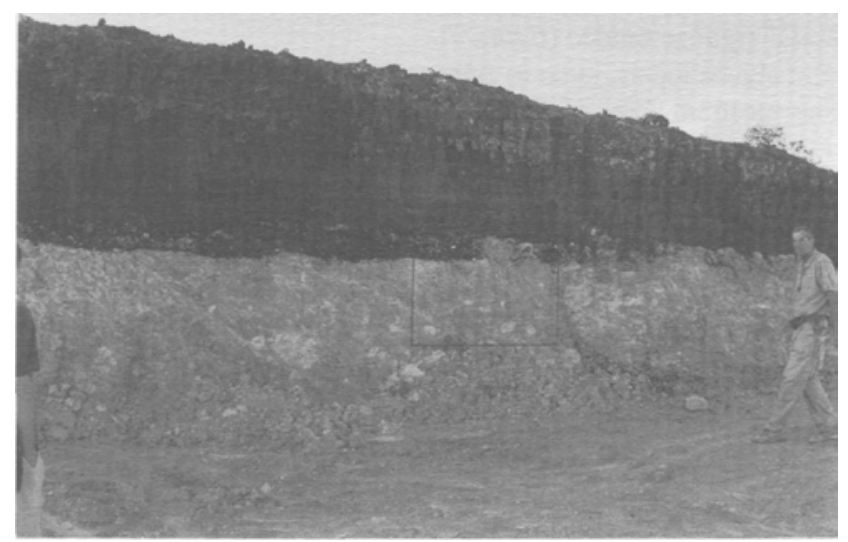

Figura 3: Solo negro argiloso que recobre brecha andesítica verde (minério verde) comfragmentos riolíticos branco avermelhados (Mina Cambia).

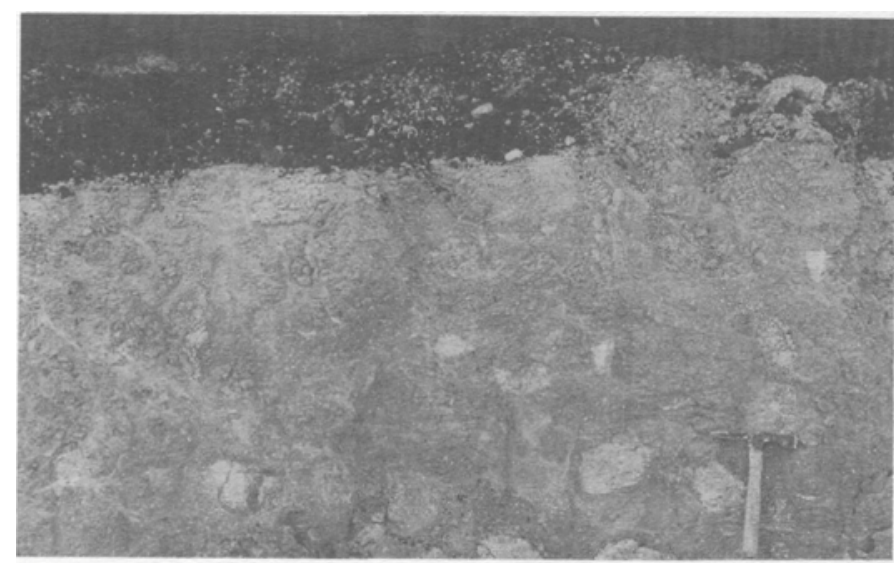

Figura 4: Detalhe da figura 3, mostrando os fragmentos de riólito em meio a matriz andesítica.

Mina de caulim Floresta A mina foi mapeada na escala $1: 500$ e mostrou uma geologia complexa, comparável à da Mina Cambuí, com características típicas de ambientes próximos a condutos vulcânicos extrusivos (Fig. 10).

$\mathrm{Na}$ área desta mina também foram identificadas duas fases vulcânicas. Todas as rochas expostas pela lavra do depósito estão intensamente argilizadas. Na Floresta, ao contrário da Mina Cambuí, as rochas têm cor branca, causada pela caulinização intensa de rochas cujas composições químicas atuais sugerem que originalmente tenham sido rochas dacíticas. O minério verde existe em muito pequena quantidade, sendo composicionalmente semelhante ao da Mina Cambuí (andesítico) e praticamente toda a produção da mina é de minério branco.

A fase vulcânica l é constituída por tufos finos, brechas vulcânicas e lapilli-tufos brechóides com fragmentos de rochas verdes. Os contatos dessas rochas têm direções próximas de E-W e os seus mergulhos são da ordem de $70-80^{\circ}$ para sul.. Ao norte do depósito aparecem tufos finos (cinzas) em meio a tufos brechóides.

A fase vulcânica 2 é na sua maior parte constituída por rochas intrusivas, sobretudo riólitos fluidais, muito laminados, encaixados por lapilli-tufos brechóides com fragmentos centimétricos verdes e por brechas da fase 1. Embora as atitudes da laminação sejam muito variáveis, os contatos desses riólitos mostram quase sempre mergulhos fortes, da ordem de $70^{\circ}$. As relações de contato sugerem que os riólitos fluidais sejam intrusivos nos lapilli-tufos brechóides.

Esta fase vulcânica exibe também tufos soldados (welded tuffs) com direções diferentes da fase 1 e mergulhos da ordem de $30^{\circ}$, em nítida discordância angular com a primeira fase, capeando os riólitos fluidais laminados. Provavelmente esses tufos são fácies explosivas associadas às intrusões dos riólitos fluidais. Pertencem, também, a esta fase as intrusões de riólito maciço da parte sul da mina e alguns pequenos diques básicos (andesíticos?) que afloram ao sul e a leste da área lavrada.

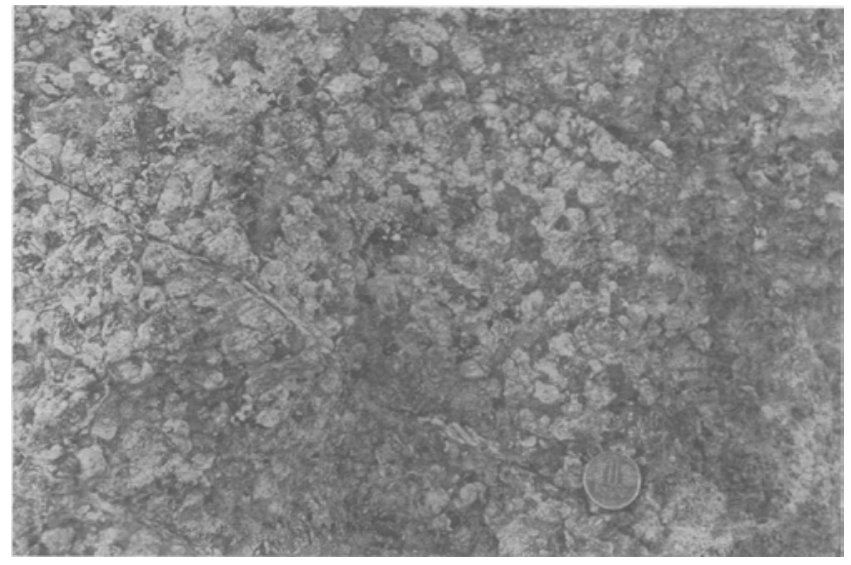

Figura 5: Lapilli-tufo da Mina Cambia. O cimento verde castanho dessa rocha é composto por opala envolvendo núcleos de esferulitos de feldspato.

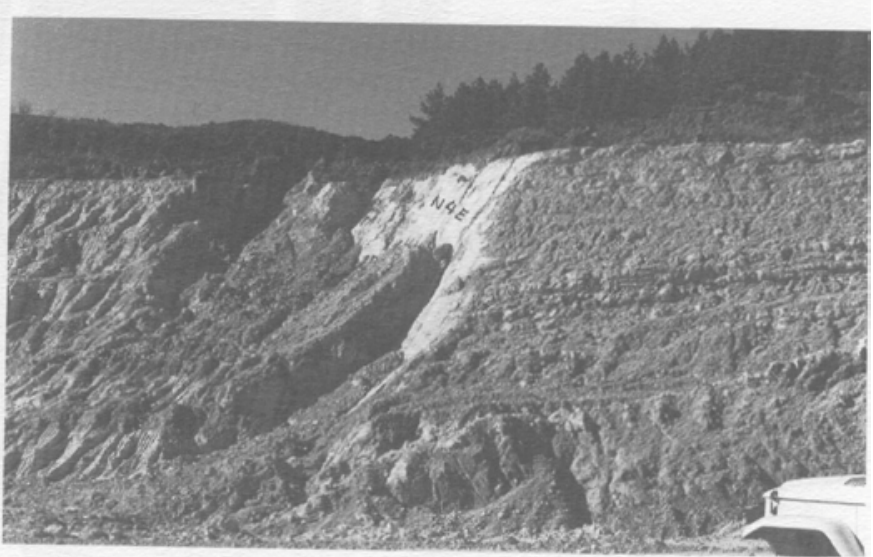

Figura 6: Plano espelhado de uma falha orientada N4E que marca o contato leste de um grande dique, com $40 \mathrm{~m}$ de largura, de riólito fluidal da Mina Cambui (Fig. 2). A metade da foto a direita do plano de falha mostra o minério verde e a parte a esquerda mostra o minério branco avermelhado.

Na porção sudeste da mina ocorrem fácies de argilitos maciços, de microconglomerados e de conglomerados argilizados, lenticulares, horizontalizados e estratifícados, depositados em discordância sobre rochas vulcânicas argilizadas. A base desses estratos é marcada por concentração de matéria orgânica (raízes e fragmentos) bem preservada, sugerindo origem recente para esses sedimentos. As estruturas sedimentares e as composições dos sedimentos sugerem origem fluvial de planície de inundação, embora a drenagem que gerou esses depósitos não mais exista no local. Esses argilitos são lavrados e esse tipo de minério doravante será denominado minério sedimentar.

Nas proximidades dos contatos do riólito fluidal, ou junto a fraturas que interceptam rochas das duas fases vulcânicas é comum, como acontece na Mina Cambuí, que as rochas, normalmente brancas devido a caulinização intensa, fiquem com cores verdes claras (fácies de fratura). Em alguns locais (ponto 17, figura 10, por exemplo) ocorrem stockworks com vênulas preenchidas por uma mistura branca de caulim e quartzo (fácies venular), como na Mina Cambuí.

Todas as fácies de rochas acima descritas, os minérios disseminados e os minérios sedimentares são recobertos por espessos mantos de minério retrabalhado (solo alóctones) e por solos argilosos negros, como na Mina Cambuí.

Apesar de cerca de 5 quilômetros distantes, as Minas Floresta e Cambuí são geologicamente muito parecidas e comparáveis ao que foi observado nas Minas do Turvo e Aruanã, situadas cerca de 8 quilômetros ao norte da Cambuí (Biondi, 1998). Nessas minas as rochas vulcânicas originais eram de composições ácidas, as fácies são tipicamente vulcanogênicas proximais, a argilização foi pervasiva e a presença generalizada de stockwork com vênulas preenchidas por material argiloso branco é uma constante. Estas características indicam 


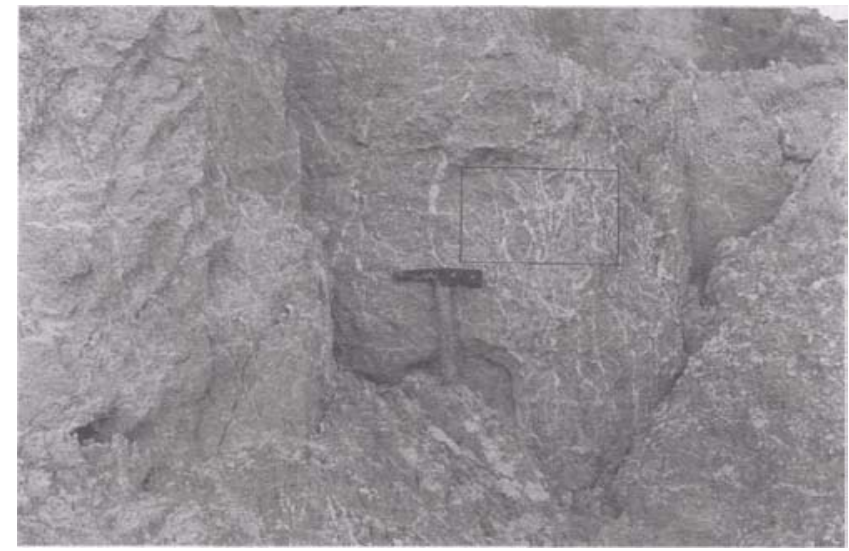

Figura 7: Ventilação em stockwork preenchida por caulim na Mina Cambia.

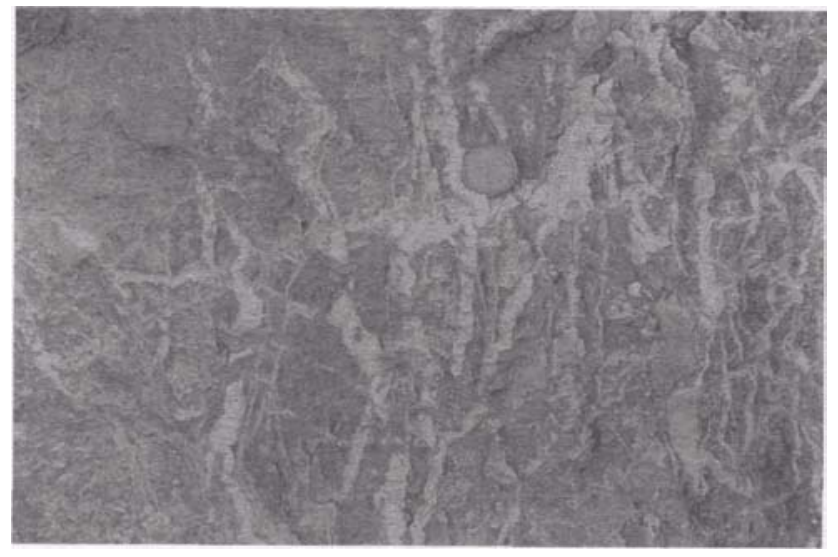

Figura 8: Detalhe da figura 7 mostrando a distribuição e a forma das vênulas hidrotennais que ocorrem localmente dentro do minério disseminado branco dos depósitos Cambia e Floresta.

um ambiente de conduto e/ou de cone vulcânico submetido a intenso hidrocataclasamento e percolado por fluidos aquosos quentes de origem vulcanogênica.

CARACTERIZAÇÃO DAS FÁCIES ARGILOSAS Foram coletadas 43 amostras de todas as fácies argilosas identificadas e 2 amostras de rochas não argilizadas. Essas amostras foram analisadas química e mineralogicamente no CETEC-LAMIR (Centro de Tecnologia Cerâmica do Laboratório de Análise de Minerais e Rochas do Departamento de Geologia da Universidade Federal do Paraná).

Mineralogia das fácies argilosas PREPARACẼO DAS AMOSTRAS E ANÁLISES As amostras argilizadas foram colocadas em suspensão em água filtrada e deionizada, agitadas e decantadas por cerca de uma hora. A parte superior da suspensão foi coletada em placa de Petri, no fundo da qual foram postas quatro lâminas de vidro, e postas a secar a temperatura ambiente. Após secas, uma das lâminas foi aquecida a $500^{\circ} \mathrm{C}$ por duas horas e outra foi umedecida em etilenoglicol por 24 horas, enquanto as duas outras permaneceram sem tratamento. Todas as amostras foram peneiradas a úmido em malha menor que $44 \mu$ ( $<325$ mesh) e foi feito um esfregaço dessa fração de cada uma das amostras.

Para cada amostra, as duas lâminas tratadas, o esfregaço e uma das lâminas sem tratamento foram analisadas em um difratômetro Philips PW 1830 do CETEC-LAMIR. As interpretações dos difratogramas foram feitas com o auxílio dos programas APD e IDENTIFY da Phillips.

Alíquotas representativas das 45 amostras coletadas foram, também, analisadas quimicamente por fluorescência de raios X (Tabela 1), permitindo obter a mineralogia "aproximada" (mineralogia normativa) das diversas fácies argilosas (Tabela 2). A partir dos difratogramas, além da identificação dos argilo-minerais, foram calculados os índices de Cristalinidade de Hinckley (ICh) da caulinita (in Gomes

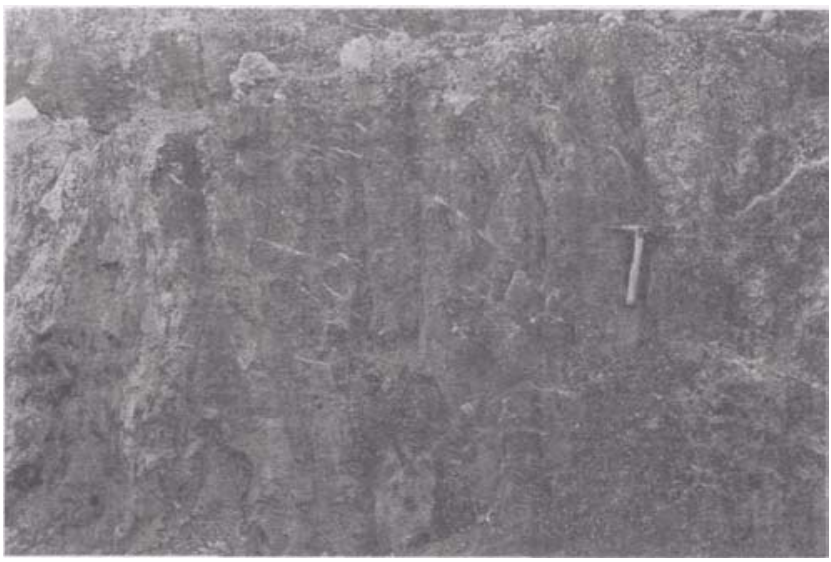

Figura 9: Minério verde (brecha andesítica) com venulações esparsas de caulim branco em porções mais afastadas dos stockworks (Mina Cambia).

1988, pag. 190) e a proporção relativa entre os argilo-minerais presentes (Martin Vivaldi, 1962), conforme Tabela 2.

MINERALOGIA DAS FÁCIES ARGILOSAS Exceto a fácies venular, no geral as fácies das rochas argilizadas das Minas Cambuí e Floresta têm caulinita, quartzo e illita como principais argilo-minerais, enquanto smectitas, haloisita e clorita são raras. São também raras argilas interestratificadas, gibbsita e pirofilita, presentes somente nas fácies de minérios sedimentares.

Várias amostras mostram a raia a $7,1 \AA$, típica do grupo da caulinita, com pico duplo, a 7,18 e a $7,16 \AA$. São também duplos os picos das raias a $3,5 \AA$, ponteando a 3,57 e a $3,59 \AA$. Essas raias sugerem a possível presença, não confirmada, de nacrita junto à caulinita.

A partir dos resultados mostrados na Tabela 1 foi feita uma análise geral das variações dos graus de cristalinidade da caulinita e das proporções relativas de caulinita, mica e quartzo normativos das amostras analisadas. Os histogramas da figura 11 mostram os resultados obtidos. A cristalinidade da caulinita varia de $\mathrm{ICh}=0,28$ (minério disseminado branco da parte sul da Mina Floresta) até 0,75 (minério disseminado verde da Mina Cambuí), porém a maior parte das amostras tem caulinita com ICh baixo, entre 0,4 e 0,5.

Entre as 43 amostras analisadas, as proporções relativas de caulinita normativa na rocha total variam entre $5,9 \%$ (argilas verdes amostradas junto às fraturas) e $90,0 \%$ (no interior das vênulas), com média próxima de $45 \%$. As proporções de mica variam de $0,8 \%$ (minério disseminado branco) até $66,3 \%$ (argilas verdes relacionadas às fraturas), com média próxima de $10 \%$, e as de quartzo variam de $10,7 \%$ (dentro das vênulas) até $83,5 \%$ (argilas verdes relacionadas às fraturas). Na tabela 2 vê-se que a composição mineralógica calculada da rocha total difere um pouco da composição real da fração mais fina $(<$ $44 \mathrm{u}$ ). Algumas amostras, como CB-6/1 (venular), CB-6/2 (concreções dentro das vênulas) ou CB-8 (minério disseminado branco) têm mica normativa em pequena proporção, porém este mineral não foi detectado nos difratogramas. Isso se explica pela presença de $\mathrm{K} 2 \mathrm{O}$ nessas rochas em outro mineral exceto a mica (adularia ou microclínio?), ou pela incapacidade do difratômetro em detectar quantidades muito pequenas de mica. Alem disso, notar que somente em duas amostras (OX-7 e OX-12 A) as proporções de mica superam a de caulinita.

Consideradas individualmente, cada uma das fácies de rocha argilizada identificadas tem as seguintes características (vide figura 12):

(a) Minério disseminado branco: na Mina Cambuí esse minério é branco-avermelhado, sendo derivado da argilização pervasiva de riólitos ou dacitos fluidais e muito laminados. Tem $20 \%$ a $65 \%$ de caulinita com ICh entre 0,30 e 0,75 , de $1 \%$ a $61 \%$ de mica e $27 \%$ a $72 \%$ de quartzo. Pode ter pequenas quantidades de haloisita (rara), de feldspato K (adularia?) e de clorita (muito rara).

(b) Minério disseminado verde: derivado da argilização pervasiva de rochas vulcânicas andesíticas, sobretudo brechas e cineritos. Tem $20 \%$ a $58 \%$ de caulinita com ICh entre 0,35 e 0,72 , de $8 \%$ a $58 \%$ de mica e $12 \%$ a $58 \%$ de quartzo. A montmorilonita foi detectada em muito pequenas quantidades em algumas amostras. A haloisita é rara e a calcita é muito rara.

(c) Minério sedimentar branco: formado em ambiente fluvial de planície de inundação, este tipo de minério foi reconhecido somente 
na parte sudeste da mina Floresta. Tem entre $28 \%$ e $65 \%$ de caulinita com ICh entre 0,27 e 0,43 , de $3 \%$ a $7 \%$ de mica e $23 \%$ a $49 \%$ de quartzo. Algumas amostras mostraram argilas interestratificadas montmorilonita/vermiculita e gibbsita (rara).

(d) Minério retrabalhado: esse minério é um solo espesso com cores bege ou branca, com resíduos de raízes e fragmento de caules. Tem de $31 \%$ a $65 \%$ de caulinita com ICh entre 0,27 e 0,42 , de $2 \%$ a $14 \%$ de mica e $20 \%$ a $57 \%$ de quartzo. Há interestratifícados clorita/vermiculita, gibbsita (rara) e clorita (rara).

(e) Facies venular: as vênulas do stockwork são preenchidas por material argiloso branco. Envolto por esse fácies argiloso há concreções, também argilosas, de cores rosadas ou creme. Essas duas fácies foram analisadas separadamente.

- A parte branca (amostras CB-6/1, CB-11 A e OX-17, na Tabela 2) contém $72 \%$ a $90 \%$ de caulinita com ICh entre 0,49 e 0,59 , de $0,3 \%$ a $10,9 \%$ de mica e $10 \%$ a $16 \%$ de quartzo. Foram feitos quatro difratogramas deste tipo de argila, em duas amostras da Mina Floresta e outras duas da Mina Cambuí (Fig. 13). É notável a semelhança na composição entre essas amostras, coletadas cerca de 5 quilômetros distantes umas das outras. Esta semelhança sugere que este material tenha sido gerado por processos similares em ambos os depósitos, e que esta gênese esteja relacionada à percolação de fluidos aquosos profundos.

- As concreções avermelhadas têm $11,5 \%$ a $16 \%$ de caulinita com Ich de 0,49 a $0,63,1 \%$ a $14 \%$ de mica e $71 \%$ a $84 \%$ de quartzo.

(f) A fácies verde clara associada a fraturas: existe em quantidades muito pequenas não sendo considerada minério. Tem $6 \%$ a $13 \%$ de caulinita, $63 \%$ a $66 \%$ de mica e $14 \%$ a $46 \%$ de quartzo. Esta é a única fácies em que as quantidades de mica e de quartzo superam a de caulinita. Essas características sugerem que junto às fraturas, onde

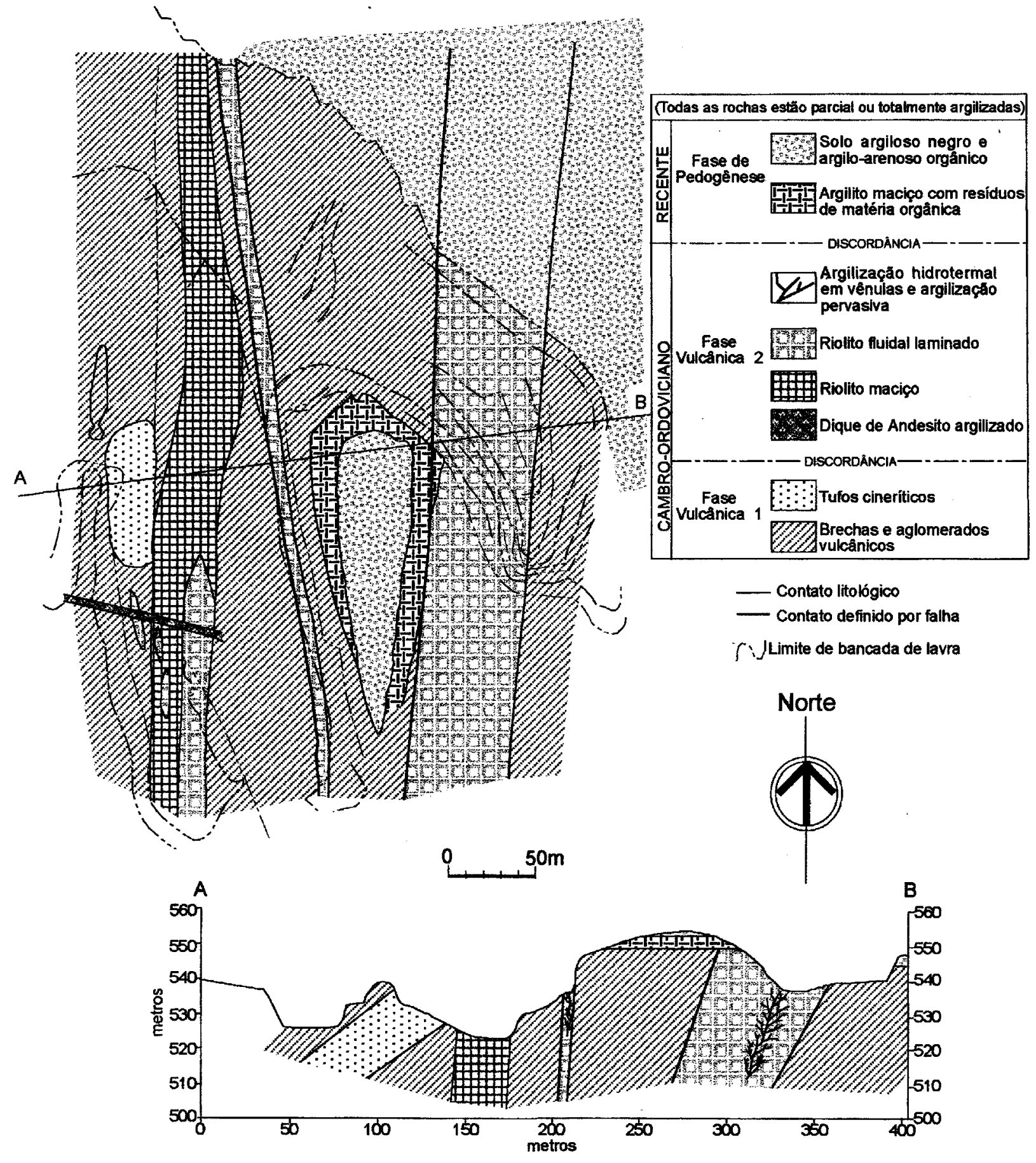

Figura 10: Mapa geológico da Mina Floresta (SC, Brasil). 
Tabela l- Composição química de amostras de minério e rochas das Minas Floresta (prefixo OX-) e Cambuí (prefixo CB-).

\begin{tabular}{|c|c|c|c|c|c|c|c|c|c|c|c|}
\hline Amostra & $\mathrm{SiO}_{2}$ & $\mathbf{A l}_{2} \mathbf{O}_{3}$ & $\mathrm{THO}_{2}$ & $\mathrm{Fe}_{2} \mathrm{O}_{3}$ & MnO & MgO & $\mathrm{CaO}$ & $\mathrm{Na}_{2} \mathrm{O}$ & $\mathbf{K}_{2} \mathbf{O}$ & $\mathbf{P}_{2} \mathbf{O}_{5}$ & $\mathbf{Z r}$ (ppm) \\
\hline CB-5 & 69,21 & 20,37 & 0,41 & 1,4 & 0,01 & 0,17 & 0,03 & $<0,01$ & 1 & 0,024 & 441 \\
\hline CB-6/1 & 52,0 & 35,73 & 0,09 & 0,82 & 0,002 & $<0,01$ & 0,01 & $<0,01$ & 0,04 & 0,017 & 127 \\
\hline CB-6/2 & 91,25 & 6,62 & 0,43 & 0,3 & 0,004 & $<0,01$ & 0,03 & $<0,01$ & 0,11 & 0,033 & 490 \\
\hline CB-6/3 & 52,38 & 30,66 & 0,43 & 3,8 & 0,087 & 0,76 & 0,01 & $<0,01$ & 4,92 & 0,027 & 508 \\
\hline CB-6/4 & 72,49 & 17,3 & 0,25 & 1,81 & 0,023 & 0,35 & 0,03 & $<0,01$ & 2,14 & 0,022 & 262 \\
\hline CB-8 & 57,9 & 26,13 & 0,41 & 0,5 & 0,002 & 0,05 & 0,02 & $<0,01$ & 0,12 & 0,062 & 427 \\
\hline CB-11 A & 82,68 & 9,95 & 0,36 & 1,41 & 0,016 & 0,33 & 0,05 & $<0,01$ & 1,66 & 0,03 & 401 \\
\hline CB-11B & 55,05 & 32,68 & 0,08 & 0,67 & 0,004 & 0,21 & 0,01 & $<0,01$ & 1,29 & 0,016 & 112 \\
\hline CB-11C & 53,48 & 29,75 & 0,39 & 2,58 & 0,023 & 0,68 & 0,01 & $<0,01$ & 3,61 & 0,031 & 427 \\
\hline CB-12 A & 69,53 & 19,52 & 0,37 & 0,38 & 0,001 & 0,02 & 0,04 & $<0,01$ & 0,09 & 0,038 & 424 \\
\hline CB-12B & 64,79 & 22,31 & 0,33 & 1,54 & 0,012 & 0,35 & 0,02 & $<0,01$ & 1,67 & 0,036 & 358 \\
\hline CB-13 & 82,58 & 11,75 & 0,24 & 0,57 & 0,005 & 0,06 & 0,03 & $<0,01$ & 0,59 & 0,02 & 402 \\
\hline CB-14 & 83,02 & 10,79 & 0,14 & 1,22 & 0,017 & 0,1 & 0,03 & $<0,01$ & 1,02 & 0,018 & 152 \\
\hline OX-1 & 64,01 & 25,67 & 0,21 & 0,48 & 0,003 & 0,1 & 0,03 & $<0,01$ & 0,27 & 0,02 & 244 \\
\hline $\mathrm{OX}-2$ & 84,02 & 10,86 & 0,2 & 0,33 & 0,006 & 0,1 & 0,02 & $<0,01$ & 0,49 & 0,021 & 238 \\
\hline OX-3 & 71,33 & 18,74 & 0,2 & 0,75 & 0,01 & 0,14 & 0,02 & $<0,01$ & 0,84 & 0,02 & 217 \\
\hline OX-5 A & 79,35 & 13,68 & 0,22 & 0,48 & 0,01 & 0,13 & 0,02 & $<0,01$ & 0,79 & 0,016 & 219 \\
\hline OX-5B & 59,22 & 29,1 & 0,34 & 0,79 & 0,012 & 0,18 & 0,02 & 0,02 & 0,87 & 0,026 & 324 \\
\hline OX-5C & 58,24 & 29,1 & 0,33 & 0,7 & 0,011 & 0,15 & 0,01 & $<0,01$ & 0,75 & 0,027 & 315 \\
\hline OX-5D & 60,24 & 25,93 & 0,36 & 0,68 & 0,01 & 0,15 & 0,02 & $<0,01$ & 0,75 & 0,026 & 313 \\
\hline OX-6A & 76,38 & 16,57 & 0,26 & 0,43 & 0,009 & 0,09 & 0,02 & $<0,01$ & 0,39 & 0,02 & 317 \\
\hline OX-6B & 57,65 & 28,79 & 0,3 & 1,77 & 0,033 & 0,31 & 0,02 & $<0,01$ & 1,98 & 0,027 & 354 \\
\hline $\mathrm{OX}-6 \mathrm{C}$ & 75,07 & 16,7 & 0,18 & 0,73 & 0,012 & 0,17 & 0,03 & $<0,01$ & 0,79 & 0,022 & 207 \\
\hline OX-6D & 79,21 & 14,19 & 0,18 & 0,47 & 0,013 & 0,1 & 0,02 & 0,01 & 0,74 & 0,017 & 189 \\
\hline OX-7 & 49,87 & 27,82 & 0,38 & 5,42 & 0,072 & 1,48 & 0,01 & $<0,01$ & 7,83 & 0,043 & 430 \\
\hline OX-9 & 69,55 & 20,42 & 0,27 & 0,79 & 0,016 & 0,26 & 0,02 & $<0,01$ & 1,34 & 0,021 & 247 \\
\hline OX-10 & 75,66 & 15,69 & 0,22 & 1,08 & 0,016 & 0,29 & 0,03 & $<0,01$ & 1,82 & 0,018 & 219 \\
\hline $\mathrm{OX}-12 \mathrm{~A}$ & 48,04 & 29,76 & 0,24 & 4,42 & 0,053 & 1,09 & 0,01 & $<0,01$ & 6,72 & 0,015 & 257 \\
\hline OX-12B & 83,9 & 10,72 & 0,17 & 0,32 & 0,005 & 0,07 & 0,03 & $<0,01$ & 0,37 & 0,02 & 194 \\
\hline$O X-13 A$ & 63,81 & 22,47 & 0,41 & 0,49 & 0,006 & 0,12 & 0,02 & $<0,01$ & 0,34 & 0,026 & 269 \\
\hline OX-13B & 64,85 & 22,89 & 0,46 & 0,59 & 0,008 & 0,14 & 0,02 & $<0,01$ & 0,48 & 0,026 & 285 \\
\hline$O X-13 C$ & 68,53 & 18,16 & 0,25 & 0,4 & 0,005 & 0,08 & 0,02 & $<0,01$ & 0,39 & 0,02 & 205 \\
\hline$O X-15 A$ & 77,43 & 12,18 & 0,15 & 0,73 & 0,007 & 0,06 & 0,04 & 1,62 & 6,83 & 0,018 & 179 \\
\hline OX-15B & 76,19 & 13,7 & 0,15 & 0,45 & 0,005 & 0,04 & 0,03 & 1,95 & 5,21 & 0,017 & 173 \\
\hline OX-15C & 71,14 & 15,02 & 0,18 & 0,5 & 0,007 & 0,08 & 0,02 & 0,39 & 6,66 & 0,019 & 203 \\
\hline OX-15D & 71,47 & 16,94 & 0,18 & 0,33 & 0,005 & 0,09 & 0,02 & 0,06 & 5,44 & 0,019 & 207 \\
\hline OX-16 & 48,59 & 29,7 & 0,38 & 4,16 & 0,051 & 1,3 & 0,02 & $<0,01$ & 7,51 & 0,034 & 486 \\
\hline OX-17 & 50,65 & 33,96 & 0,05 & 0,86 & & & 0,02 & $<0,01$ & 0,07 & 0,016 & 81 \\
\hline$O X-20 A$ & 61,48 & 26,06 & 0,27 & 1,2 & 0,017 & 0,24 & 0,02 & 0,01 & 1,38 & 0,034 & 295 \\
\hline OX-20B & 73,14 & 16,69 & 0,23 & 0,75 & 0,016 & 0,19 & 0,03 & $<0,01$ & 1,26 & 0,013 & 189 \\
\hline$O X-20 C$ & 54,99 & 30,09 & 0,4 & 1,2 & 0,016 & 0,25 & 0,01 & $<0,01$ & 1,35 & 0,022 & 314 \\
\hline OX-20D & 75,57 & 15,85 & 0,59 & 0,63 & 0,007 & 0,12 & 0,04 & $<0,01$ & 0,31 & 0,014 & 282 \\
\hline$O X-20 E$ & 74,22 & 9,93 & 1,59 & 3,56 & 0,01 & 0,27 & 0,03 & $<0,01$ & 0,32 & 0,029 & 458 \\
\hline $\begin{array}{l}\text { Riolito } \\
\text { Cambuí }\end{array}$ & 73,25 & 13,44 & 0,28 & 1,83 & 0,035 & 0,09 & 0,03 & 2,45 & 5,52 & 0,023 & 295 \\
\hline $\begin{array}{l}\text { Riolito } \\
\text { Floresta }\end{array}$ & 75,07 & 12,32 & 0,14 & 2,16 & 0,018 & 0,07 & 0,09 & 2,58 & 6,46 & 0,019 & 163 \\
\hline
\end{tabular}

ocorre esse tipo de rocha, as temperaturas de cristalização dos minerais tenham sido mais elevadas. As fraturas devem ter sido os caminhos de exalação de fluidos aquosos mais quentes que aqueles que preencheram as fraturas dos stockworks, onde o mineral precipitado foi dominantemente a caulinita.

(g) Solo negro: é o solo de cobertura mais superficial em todos os depósitos, desenvolvendo-se sobre o solo (minério) retrabalhado. Tem cerca de $22 \%$ de caulinita, $3 \%$ de mica e $62 \%$ de quartzo. A cor negra é conseqüência da grande quantidade de matéria orgânica, raízes e fragmentos de caules (solo de turfeira). Tem quantidades importantes de ilmenita/magnetita e pouca vermiculita.

DISCUSSÃO SOBRE A MINERALOGIA Nas amostras analisadas não foi constatada qualquer relação entre a cristalinidade e a quantidade de caulinita nas diversas fácies argilosas descritas (Fig. 14). Não há, também, qualquer fácies que se diferencie por uma classe específica de cristalinidade. O grau de cristalinidade, expresso pelo indice de Cristalinidade de Hinckley (ICh), varia entre 0,26 e 0,75 , em uma escala de $\mathrm{O}$ até 1,0 , e nesse intervalo as diferentes fácies argilosas se misturam sem distinção.

As relações entre as quantidades de caulinita normativas nas fácies argilosas e as quantidades de quartzo (figura 15) e/ou de mica (figura 16) mostram a existência de duas zonas argilosas. Uma zona, denominada hidrotermal, inclui as fácies argilosas contidas nas vênulas dos stockworks (fácies venular, rica em caulinita e pobre em mica e quartzo), as fácies relacionadas a fraturas (fácies de fratura, com baixos teores de caulinita e ricos em mica) e as encaixantes dessas fraturas e vênulas. Uma outra zona, denominada zona supergênica, inclui todas 
Tabela 2 - Composições mineralógicasmodais de amostras de minério e rochas das Minas Floresta (prefixo OX-) e Cambui (prefixo CB-).

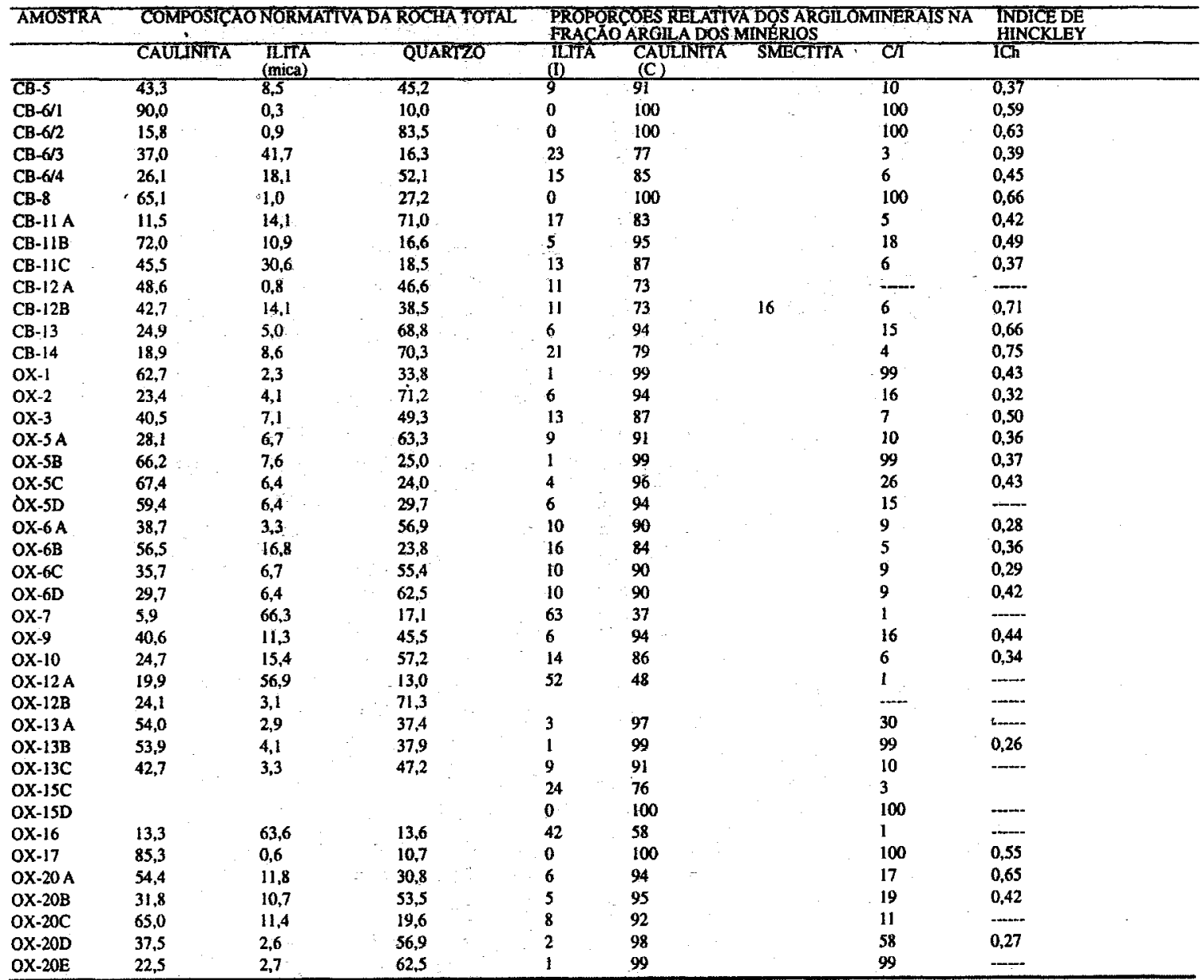
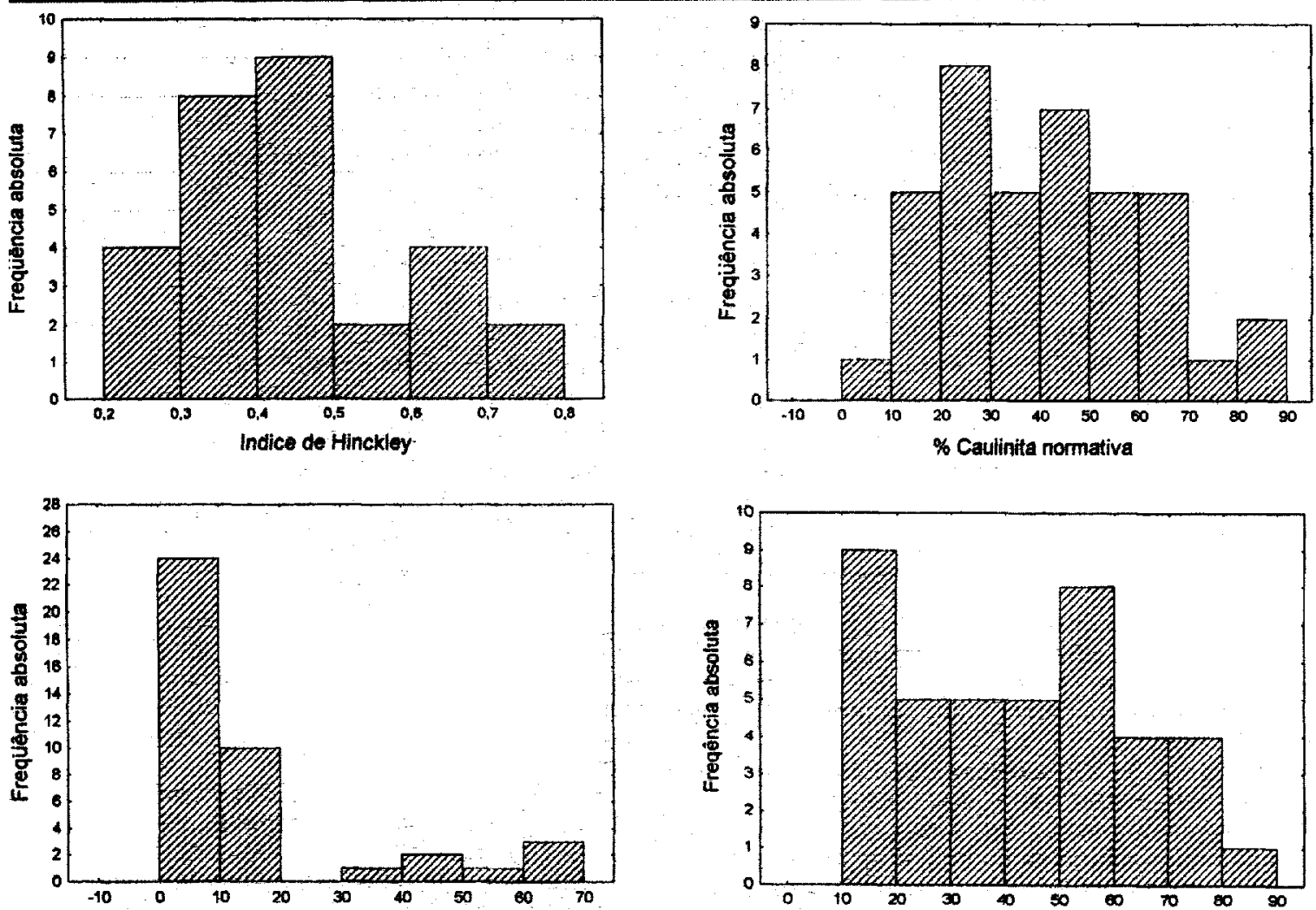

$\%$ Mica normativa

$\%$ Quartzo normativo

Figura U - Histograma dos valores do indice de Cristalinidade de Hinckley e das proporções de caulinita, illita e quartzo normativos nas rochas das Minas Cambui e Floresta. 


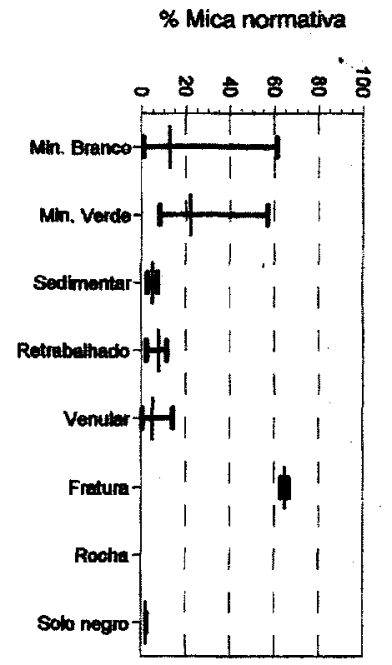

\% Quartzo normativo

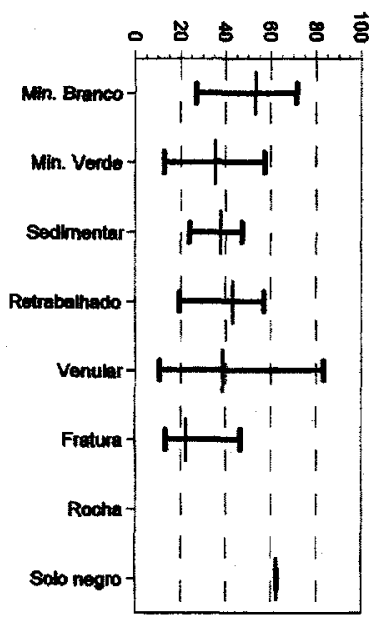

Figura 12 - Variações do índice de Crístalinidade de Hinckley e dos teores de caulinita, illita e quartzo das fácies argilosas das Minas Cambui e Floresta.

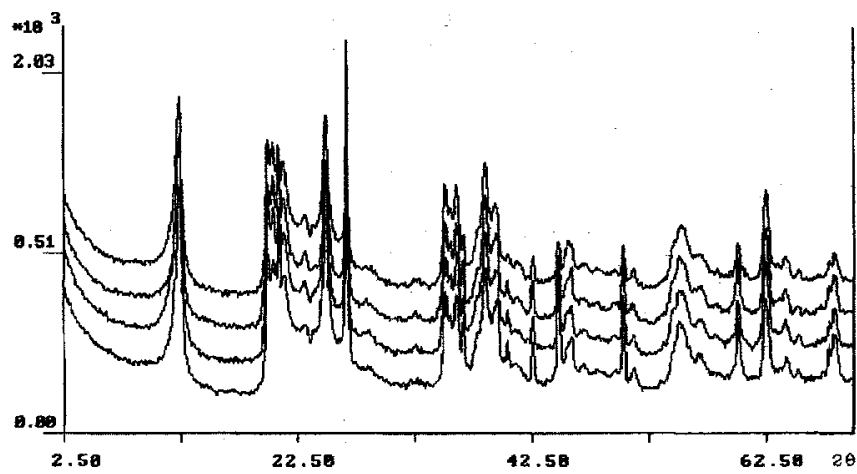

Figura 13 - Difratogramas do material argiloso que preenche as vênulas dos stockworks das Minas Cambui e Floresta. Os dois difratogramas superiores são de amostras da Mina Floresta e os dois

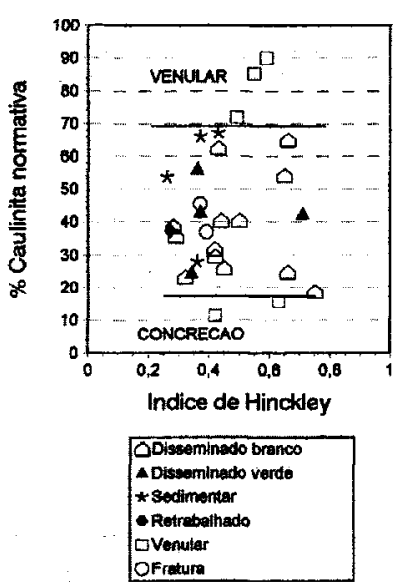

Figura 14 - Diagrama que mostra a\% de caulinita normativa $x$ índice de Hinckley (ICh) das amostras de minério das Minas Cambui e Floresta (mesma legenda da figura 15). Notar nessa figura que não há relação entre o ICh e a quantidade de caulinita das fades argilosas.

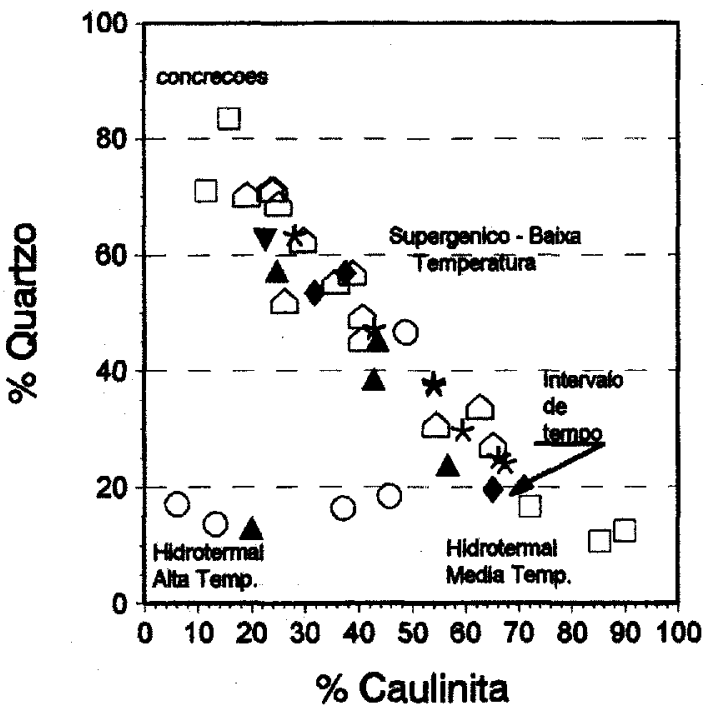

\begin{tabular}{|l|}
\hline$\triangle$ Disseminado branco \\
A Disseminado verde \\
* Sedimentar \\
- Retrabalhado \\
$\square$ Venular \\
OFratura \\
$\nabla$ Solo negro \\
\hline
\end{tabular}

Figura 15 - Diagrama que mostra a\% de caulinita modal versus a \% de quartzo modal de minérios das Minas Cambui e Floresta. Notar que os pontos representativos das composições das diversas fades argilosas ocupam domínios contínuos no diagrama.

as outras fácies. Em visão tridimensional (figura 17) nota-se que a passagem da fácies de alta temperatura (fácies associada às fraturas) para a de média temperatura (fácies associadas às vênulas) até a de baixa temperatura (fácies supergênicas) ocorre gradativamente, nessa ordem, com diminuição dos teores de mica e aumento dos teores de caulinita e de quartzo. A amostra CB-12 A, de fratura, porém situada em meio as amostras da zona supergênica (figuras 15 e 16), foi coletada junto ao contato de um dos diques riolíticos da Mina Cambuí (figura 2), o que, aparentemente, explica o enriquecimento em quartzo no local 


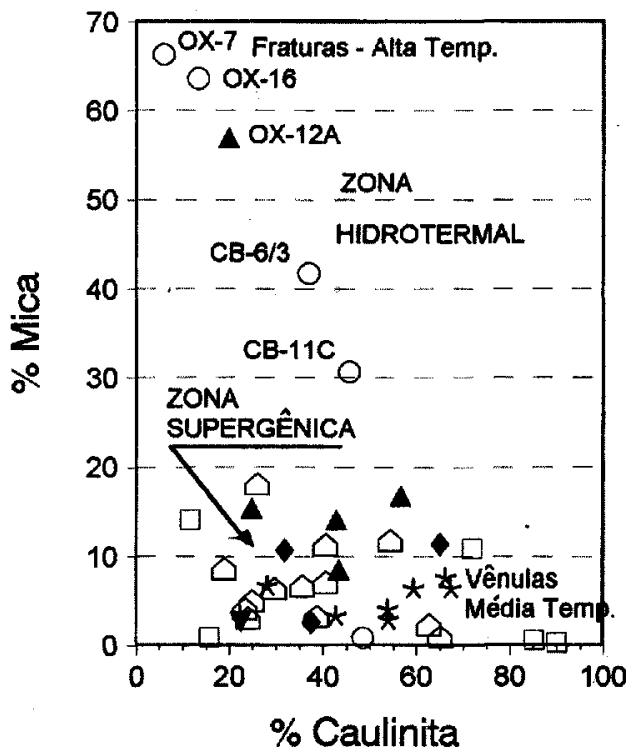

\begin{tabular}{|l|}
\hline Disseminado branco \\
A Disseminado verde \\
* Sedimentar \\
- Retrabalhado \\
$\square$ Venular \\
OFratura \\
- Rocha \\
\hline
\end{tabular}

Figura 16 - Diagrama mostrando a \% de caulinita modal versus a \% modal de micas de amostras de minério das Minas Cambuie Floresta. Os pontos representativos das composições das fades de fraturas, de vênulas e supergênica ocupam domínios contínuos mas distintos no diagrama.

e na amostra. A OX-12 A, ao contrário, é minério verde e nas figuras 15 e 16 o ponto representativo desta amostra se situa entre os pontos de amostras típicas de zona de fratura. Essa amostra é uma brecha com fragmentos de rocha verde, provavelmente originados em uma fratura antiga, destruída durante a primeira fase de vulcanismo descrita na Mina Floresta.

Notar que não há discontinuidade composicional entre as amostras provenientes de vênulas e as supergênicas, embora os pontos representativos dessas amostras ocupem zonas diferentes nos diagramas. Isto pode ser: (a) uma conseqüência da ação supergênica sobre o material argiloso que preenche as vênulas ou; (b) as argilas supergênicas formaram-se a temperaturas imediatamente abaixo e em seqüência às vênulas. Provavelmente ambos os fatores fazem essa continuidade composicional entre esses fácies.

Caso a pluma hidrotermal tenha alcançado a superfície na época em que estava ativa, a argilização supergênica começou, e continua até hoje, ao mesmo tempo que a hidrotermal. Nesse caso não haveria efetivamente um intervalo de tempo sem geração de argilo-minerais

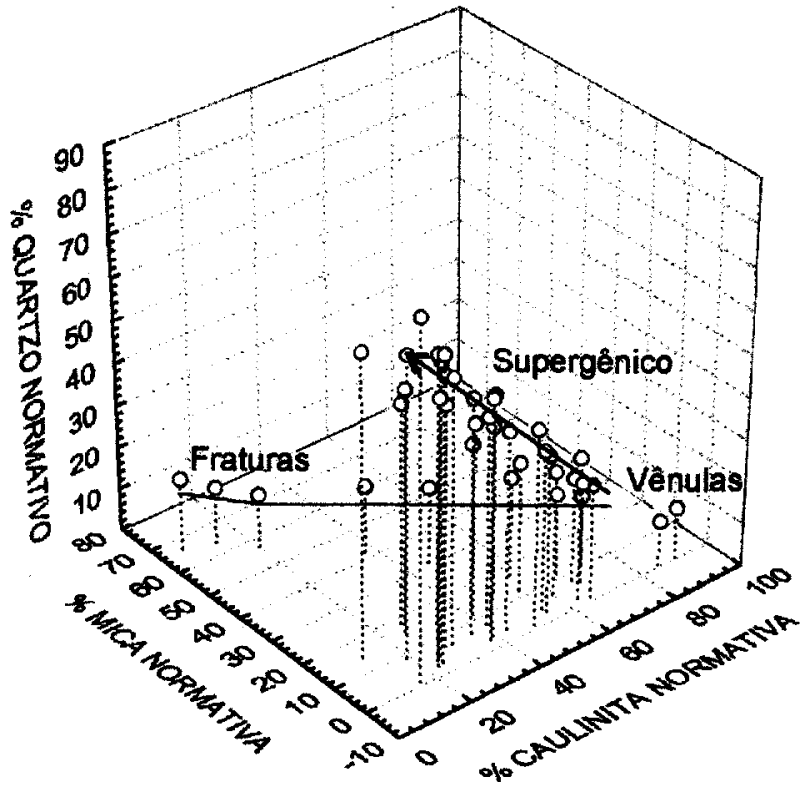

Figura 17: Diagrama tridimensional de pontos representativos das composições em quartzo, mica e caulinita normativos de amostras de minérios das Minas Cambui e Floresta. Notar que a gradação entre as composições das fades de fratura, de vênulas e supergênica ocorre com a variação concomitante dos teores dos três minerais,

entre a época da origem da fácies venular e a das argilas supergênicas. Se o hidrotermalismo foi profundo e a pluma hidrotermal não atingiu a superfície, as fácies supergênicas observadas hoje nos depósitos descritos começaram a se desenvolver somente quando as rochas hidrotermalizadas foram exumadas pela erosão. $\mathrm{O}$ desenvolvimento da ação supergênica, nesse caso, foi muito facilitado devido a fragilidade das rochas, que tiveram suas estruturas originais destruídas pelo hidrotermalismo.

CONCLUSÕES Os depósitos de caulim Cambuí e Floresta formaram-se em ambientes vulcânico proximais, e exibem fácies litológicas típicas de conduto e cone vulcânicos. A argilização pervasiva das rochas gerou várias fácies argilosas, reconhecidas por suas características físicas e pelo ambiente onde se formaram e denominadas minério branco, minério verde, fácies venular, fácies de fratura, fácies sedimentar, fácies de solo retrabalhado e fácies de solo negro, além da rocha inalterada. A mineralogia dessas fácies permite definir uma linha evolutiva coordenada pela diminuição da temperatura do ambiente onde se formaram, desde a fácies de fratura, micáceo, provavelmente de alta temperatura $\left(300^{\circ} \mathrm{C}\right.$ a $\left.500^{\circ} \mathrm{C}\right)$, até a fácies venular, caulínica, provavelmente de média a baixa temperatura $\left(100^{\circ} \mathrm{C}\right.$ a $\left.300^{\circ} \mathrm{C}\right)$. A fácies venular grada para as fácies supergênicas, de baixa temperatura $\left(20^{\circ} \mathrm{C}\right.$ a $50^{\circ} \mathrm{C}$ ), não tendo sido percebida qualquer descontinuidade nas suas composições mineralógicas. Caso a supergênese tenha se iniciado apenas após a exumação das rochas hidrotermalizadas, há uma gradação composicional, mas não temporal, entre os fácies venular e supergênico.

\section{Referências}

Basei, M.A .S. \& Teixeira, W. 1987. Geocronologia do Pré-Cambriano/Eopaleozóico de Santa Catarina. Texto explicativo do mapa geológico de Santa Catarina na escala 1:500.000. DNPM/SCTME(SC), 215p.

Biondi, J.C. 1998. Modelo genético dos depósitos de caulim Floresta, Cambuí, Turvo e Aruanã (SC-BR). In, SBG, Congresso Brasileiro de Geologia, 40, Velo Horizonte, Anais...., p.

Daitx, E.C. 1979. Projeto Guaratubinha-Pien. BRASIL.Convênio DNPM/CPRM. Relatório inédito, São Paulo, 184p.

Gomes, C. F. 1988. Argilas - O que são e para que servem. Ed. Fundação Calouste Gulbenkian (Lisboa), $457 \mathrm{p}$
Martin Vivaldi, J.L. 1962. L'analyse par spectrographie et par diffraction de rayons X. Special Publ. Philips, (Colloque de Madrid), 2:231-249.

Silva, L.C. 1987.Textos Básicos de Geologia e Recursos Minerais de Santa Catarina. Texto do mapa geológico de Santa Catarina na escala $1: 500.000$. DNPM/SCTME(SC) $215 \mathrm{p}$

Manuscrito A-997 Manuscrito A-997
Recebido em 19 de junho de 1998 Revisão dos autores 30 de setembro de 1998 Revisão aceita em 10 de outubro de 1998 